\title{
Resistance of Transgenic Hybrid Triploids in Populus tomentosa Carr. Against 3 Species of Lepidopterans Following Two Winter Dormancies Conferred by High Level Expression of Cowpea Trypsin Inhibitor Gene
}

\author{
By Q. Zhang, Z. Y. ZhanG*), S. Z. LIN and Y. Z. LIN
}

\begin{abstract}
Key Laboratory of Genetics and Breeding in Forest Trees and Ornamental Plants, Ministry of Education, Beijing Forestry University, Beijing 100083, China
\end{abstract}

(Received 21 $1^{\text {st }}$ February 2005)

\begin{abstract}
Hybrid triploid poplars $[(P$. tomentosa $\times$ P. bolleana $) \times$ $P$. tomentosa] genetically engineered with cowpea trypsin inhibitor (CpTI) gene have been out-planted in field for two years. They were used to detect their efficacy against 3 species of poplar defoliators: forest tent capterpillar, Malacosoma disstria Hübner, gypsy moth, Lymantria dispar Linnaeus and willow moth, Stilpnotia candida Staudinger by using detached leaves and for the purpose of identifying the $C p T I$ gene at the molecular level. Foliage of transgenic poplars elicited an increase in larval mortality rate and a decrease in foliage consumption, wet weight gains, faeces excretion, deposited pupae number and pupae weight, thus indicating its effectiveness in affecting the growth, development and fecundity of larvae rather than only directly killing them. PCR and Southern blotting analyses confirmed the stable incorporation of $C p T I$ gene while proteinase inhibitory assays disclosed its high level expression in the two-field-season of transgenic trees. Efficacious insect resistance and higher content of $\mathrm{CpTI}$ in foliage were found in transgenic clone TG04, TG07, TG08 and TG71, demonstrating a correspondence between the insect resistance level and the CpTI content in the foliage of transgenic poplar.
\end{abstract}

Key words: Populus tomentosa Carr.; CpTI gene, transgenic poplar, Lepidoptera, insect resistance, proteinase inhibitory assay, PCR, Southern blotting.

\section{Introduction}

Chinese White Poplar (Populus tomentosa Carr.) is one of the indigenous tree species of white poplar (Section leuce) in China. It is found in the country's middleeastern region, and covers about one million $\mathrm{km}^{2}$ (approximately $1 / 9$ of the total area of China). It is characterized by rapid growth, high yield and short rotation and is commonly known for the superior timber that it yields, and is widely used as an important afforestation and landscape species in the north of China (ZHU and ZHANG, 1997). Moreover, the newly bred hybrid triploid poplar $[(P$. tomentosa $\times$ P. bolleana $) \times P$. tomentosa $]$ (ZHANG et al., 1992, 1997b) has demonstrated great improvement in photosynthetic rate (LI et al., 2000a) and wood quality (PU et al., 2002; XING et al., 2002) in addition to the traits in diploid $P$. tomentosa Carr., and is a good candidate for genetic engineering as a result of the establishment of an improved regeneration system

\footnotetext{
*) Author for further correspondence: zhangzy@bju.edu.cn

Phone + Fax: 86-10-62338502
}

(HAO et al., 1999a; Lu et al., 2001) and its high sterility rate (ZHANG et al., 2000), thus promising a dramatically decreased possibility of transgene dispersal from engineered poplars to wild types through pollen hybridization and also ensuring high biosafety of engineered poplars to environment.

However, P. tomentosa Carr., like other poplar species, is vulnerable to many insects. It is the host to more than 200 species of insects, most notably to 30 kinds of Lepidoptera and Coleoptera (including underground insects, leaf or twig damaging insects and stem borers), which pose the most serious threat (XU, 1988). Over the past few decades, various methods have been utilized to reduce this insect problem. The traditional spray application of insecticidal proteins and chemical toxins is effective in that it kills the insects instantly, but it has devastating long-term effects for the environment. Traditional breeding for insect resistance is a difficult task in trees with long rotations and limited resistant hereditary resources (XU, 1988; WHITMAN et al., 1996; ZHANG, 1997a). But genetic engineering provides an opportunity to transfer new specific traits of interest into valuable genotypes (CAMPBELL et al., 2003). To date, scientists world-wide have been able to genetically engineer poplars resistant to insects by relying mainly upon genes encoding insecticidal proteins of Bacillus thuringiensis $\delta$-endotoxin (MCCown et al., 1991; Wu et al., 1991; TIAN et al., 1993, 2000; PANNETIER et al., 1997; CHEN et al., 1995) and those encoding proteinase inhibitor (KLOPFENSTEIN et al., 1991; LEPLE et al., 1995; URWIN et al., 1995; HEUCHELIN et al., 1997; CoNFALONIERI et al., 1998; HAO et al., 1999b; LI et al., 2000b; Delle Donne et al., 2001; YANG et al., 2003).

Cowpea trypsin inhibitor (CpTI) is a small polypeptide belonging to the Bowman-Birk type of double-headed serine proteinase inhibitors (HAMMOND et al., 1984; HILDER et al., 1989; RYAN, 1989, 1990; LIU et al., 1993), and has high efficacy in affecting growth and development of insects including Lacanobia oleracea (BELL et al., 2001) and a wide range of other Coleoptera, Diabrotica species, Anthronomus grandis, Lepidoptera and Orhoptera (HILDER et al., 1990). Moreover, it is less likely to induce resistance of insects due to the fact that it binds competitively to the comparatively conserved active site of digestive enzymes, and is highly sensitive to pepsin, thus promising it safety to mammals (RYAN et al., 1989; HILDER et al., 1989). Therefore, it is considered to be an ideal candidate for yielding transgenic plants 
resistant to predators (GHOSHAL et al., 2001). This was firstly demonstrated by HILDER et al. (1987) when cowpea trypsin inhibitor (CpTI) gene was transferred from Vigna unguiculata to tobacco. The transgenic tobaccos conferred resistance to a wide range of insect pests, such as Lepidoptera Heliothis and Spodoptera. It was followed by the genetically engineered rice (XU et al., 1996), tobacco (GHoshal et al., 2001) and hybrid triploid poplar [(P. tomentosa $\times$ P. bolleana) $\times$ P. tomentosa $]$ (HAO et al., 1999b), etc.

In the hope of providing a new poplar variety to meet the pressing afforestation need in China, the hybrid triploid poplar $[(P$. tomentosa $\times$ P. bolleana $) \times P$. tomentosa] was further improved in resistance against insect attack by genetically engineering it with $C p T I$ gene at our university, and integration and expression of the foreign gene in the host genome had been characterized by our preliminary studies performed on regenerated shoots and plantlets (HAO et al., 1999b). They were then planted in the field for more than two field seasons without insect feeding bioassays or further studies at molecular level. Two-field-season of plantation in field increased our interest in figuring out the efficacy of transgenic poplars to defoliators and our curiosity about the integration status and the expression level of $C p T I$ gene in host genome.

In this study, we detail the use of insect feeding bioassays to evaluate the efficacy of two-field-season of genetically engineered poplars against 3 species of poplar defoliators and of PCR, Southern blotting and proteinase inhibitory assays to identify $C p T I$ gene and its encoded protein at the molecular level. Increased insect resistance of transgenic poplars was identified, stable incorporation and active expression of $C p T I$ gene in engineered poplars were confirmed, efficacious insect resistance and higher content of $\mathrm{CpTI}$ were detected in 4 transgenic clones revealing a correspondence between the insect resistance level and the CpTI content in the foliage of transgenic poplars.

\section{Materials and Methods}

\section{Plant Materials}

Transgenic hybrid triploid poplars $[(P$. tomentosa $\times P$. bolleana) x $P$. tomentosa] were produced by Agrobacterium tumefaciens-mediated transformation as described by HAO et al. (1999b). The plasmid T-DNA (pBin $\Omega$ SCK) harbored the $C p T I$ gene and kanamycin resistance gene NPTII from Tn5, both of which were under the control of a constitutive CaMV $35 \mathrm{~S}$ promoter in 5 ' end and a T-nos terminator in 3' end. A SKTI signal peptide and a KDEL coding sequence were fused in the 5 ' region and 3' end of $C p T I$ gene, respectively, thus forming a SignalCpTI-KDEL construct. Between the promoter and the modified $C p T I$ gene construct is a $68 \mathrm{bp}$ long Omega element from a Tobacco Mosaic Virus (TMV) gene encoding a $126 \mathrm{KD}$ protein, which is located in the untranslation region of upstream transcription sequence, and has the potential to enhance the expression of downstream gene.

Both transformed and untransformed (control) poplars were propagated from micro-cultured shoots and 3-10 individual seedlings for each clone (control included) and were then transplanted in Houbajia field, in a northern suburb of Beijing in fall of 2000.

\section{Insect Materials}

The early 3rd-instar forest tent caterpillar, Malacosoma disstria Hübner, were collected from branches of Malus micromalus Makino at our university and reared with the foliage of Malus micromalus Makino for $2 \mathrm{~d}$. The gypsy moth, Lymantria dispar (L.) was reared from the egg bands provided by Forest Protection Laboratory at our university until early 3rd-instar, at which point the larvae were fed with the foliage of Diospyros kaki (L.). The first generation willow moth, stilpnotia candi$d a$ staudinger were gathered in their later 5th-instar from the Populus canadensis Moench ( $P$. deltoides $\times$ P. nigra) in front of Forest Protection Station at our campus and were transferred to the greenhouse for feeding assay. 3 egg bands produced by the first generation willow moth were collected for the preparation of the second-generation larvae and the larvae were reared until 3rd-instar. All larvae were reared in a controlled environmental chamber at $27^{\circ} \mathrm{C}$ and a photoperiod of $16: 8$ (L: D) h.

\section{Insect bioassay and data analysis}

Four non-choice laboratory feeding assays were launched on 18 April, 18 May, 9 June and 28 June using early 3rd-instar forest tent caterpillar, later 5th-instar willow moth, early 3rd-instar gypsy moth and early 3rdinstar willow moth, respectively. The leaves with the same size were excised at the base of the petiole from each tree, sealed in plastic sandwich bags, and taken to the laboratory. The same poplars were used for all 4 assays.

For each insect bioassay, a group of 10 to 20 defoliators held in a glass vial $(7.5 \mathrm{~cm}$ diameter, $12.5 \mathrm{~cm}$ height) were allowed to feed on the leaves of each clone (3 replicate treatments per clone). To maintain the humidity of air and leaves, a piece of wet filtration paper was placed on the bottom of each container. The feeding foliage was replaced with a new one every other day. Larvae were removed from original rearing leaves the day before the launching of insect bioassays to void the mid-gut of insects before weighing them.

The mortality rates of larvae feeding on the foliage of each clone was recorded and analyzed to evaluate the toxicity of each transgenic clone to defoliators.

All original defoliators in each vial and the final survival larvae were grouply weighed, respectively, to calculate the mean wet weight gains of insects. Faeces excreted in a period of $8 \mathrm{~d}$ were collected and dried overnight in an oven at $60^{\circ} \mathrm{C}$ and the mean dry weight gains were used as a measure of food intake (JOHNSTON et al., 1993). By the end of the trial performed on the second-generation of willow moth larvae, male and female pupae weight were measured respectively, the egg numbers deposited were counted to estimate their fecundity.

All of the data from insect bioassays were analyzed using one-way analysis of variance (ANOVA) and subse- 
quent FisHER's multiple comparisons if there are significant differences as described by ROSNER (2004).

\section{Assay of cowpea trypsin inhibitor}

Leaf protein extraction was performed as described previously (PERLAK et al., 1991). Assay of trypsin proteinase inhibitor with the casein as the substrate of trypsin was performed as also described previously (HAO et al., 1999; XU et al., 1996). 0, 0.4, 0.8, 1.2, 1.6, 2.0 and $2.4 \mu \mathrm{g}$ of cowpea trypsin inhibitors were mixed with trypsin respectively, and incubated at $27^{\circ} \mathrm{C}$ for 30 minutes, followed by the addition of $100 \mu \mathrm{g}$ substrate of trypsin. The casein with the hydrolysis was incubated at $30^{\circ} \mathrm{C}$ for $1 \mathrm{~h}$. Data derived from the $\mathrm{OD}_{280}$ were used to draw the standard inhibitory curve. The same procedure for construction of standard inhibitory curve was used in the inhibitory reaction of plant CpTI to trypsin, except that the cowpea trypsin inhibitor was replaced with $50 \mu \mathrm{g}$ extracts from the young leaves and old leaves of each clone. The quantification of plant CpTI was calculated according to the data of $\mathrm{OD}_{280}$ achieved from the standard inhibitory curve.

\section{PCR and Southern analysis}

DNA was extracted from poplar leaves as described by ROGERS and BENDICH (1985). PCR analysis was performed with gene specific primer combination 5'ATGAAGAGCACCATCTTCTTTGCTC-3' and 5'CTTACTCATCATCTTCATCCCTGG-3' designed according to sequence of the CpTI gene cloned by LIU et al. (1993). PCR amplification was performed on an ABIthermocycler (9700) and in PCR buffer (10 mM Tris $\mathrm{pH}$ 8.0, 0.01 percent gelatin, 0.1 percent Triton $\mathrm{X}-100$, $80 \mathrm{mM} \mathrm{KCl}, 3.5 \mathrm{mM} \mathrm{MgCl}_{2}$ ) containing $25 \mathrm{pM}$ of each primer, $250 \mu \mathrm{M}$ of each dNTP (Pharmacia Ultra pure), 20-100 ng of target DNA, 5 units of Taq DNA polymerase (Promega). Reaction volumes were made up to $50 \mu \mathrm{l}$. Amplification of $C p T I$ genes was achieved by an initial denaturation step at $94^{\circ} \mathrm{C}$ for 5 min followed by addition of the polymerase and 34 cycles of $94^{\circ} \mathrm{C}, 30 \mathrm{~s}$; $55^{\circ} \mathrm{C}, 60 \mathrm{~s} ; 72^{\circ} \mathrm{C}, 60 \mathrm{~s}$, with a final extension step of 10 min at $72^{\circ} \mathrm{C}$. Amplified products were separated on $1.5 \%$ agarose gel in $1 \times$ TAE buffer. Fragments were viewed under UV light after gel staining with ethidium bromide and photographed using an Olympus Digital Camera. DNA fragment sizes were determined by comparison to [lambda] HindIII digested and Pharmacia 100bp ladder size markers.

As for Southern blotting analysis, $10 \mu \mathrm{l}(1 \mu \mathrm{g} / \mu \mathrm{l})$ plant genomic DNA was subject to overnight digestion by $1 \mu \mathrm{l}$ Hind III ( $5 \mathrm{U} / \mu \mathrm{l})$ at $37^{\circ} \mathrm{C}$, electrophoresed through $1.0 \%$ $(\mathrm{w} / \mathrm{v})$ agarose, and blotted onto hybond $-\mathrm{N}^{+}$membrane (Amersham) using standard protocol (SAMBRooK et al., 1989). The DNA was cross-linked to membrane using HL-2000 HybriLinker (UVP) prior to prehybridization for $1 \mathrm{~h}$ at $42^{\circ} \mathrm{C}$ in DIG Easy Hyb solution provided in DIG High Prime DNA Labeling System and Detection Starter Kit I (Roche). DNA probe of $C p T I$ gene was prepared by artificially synthesizing a $100 \mathrm{bp}$ fragment of $C p T I$ gene specific sequence due to the unavailability of positive Agrobacterium tumefaciens containing the gene of interest and then labeling it through mixing it with the DIG-High Prime contained in the Kit overnight at $37^{\circ} \mathrm{C}$, and hybridization performed at $42^{\circ} \mathrm{C}$ for $16 \mathrm{~h}$. The membrane was rinsed twice in ample $2 \times$ SSC, $0.1 \%$ SDS at room temperature under constant agitation for 5 min, and washed $2 \times 15 \mathrm{~min}$ in $0.5 \times \mathrm{SSC}, 0.1 \% \mathrm{SDS}$ (prewarmed to wash temperature) at $65^{\circ} \mathrm{C}$ under constant agitation. It was followed by a $5 \mathrm{~min}$ rinse in Washing buffer, $30 \mathrm{~min}$ successive incubation in both Blocking solution and Antibody solution, 2 x 15 min washing in Washing solution and 5 min equilibration in Detection buffer. Hybridization bands were revealed by incubation without agitation in freshly prepared color substrate solution containing NBT/BCIP.

\section{Results}

\section{Fatal effectiveness}

To determine the fatal effectiveness of transgenic poplars to Lepidoptera, 3 species of defoliators, 12 transgenic poplar clones and one untransformed control were used to conduct insect bioassays. The mortality rates of forest tent caterpillar, gypsy moth and willow moth were recorded after $20 \mathrm{~d}, 5 \mathrm{~d}$ and $38 \mathrm{~d}$ of incubation, respectively. Analyses revealed significant interaction between genotype and larval mortality rates of three species of insects $(\mathrm{P}=3.2 \mathrm{E}-10,4.4 \mathrm{E}-4$ and $9.8 \mathrm{E}-9$, for forest tent caterpillar, gypsy moth and willow moth, respectively). All larvae feeding on foliage from transgenic poplars demonstrated greater mortality rates than the untransformed control. After checking the average mortality rates of 3 species of larvae feeding on foliage from the same poplar clone, significant differences in fatal toxicity to larvae were found among all poplar clones $(\mathrm{P}=0.016)$. The mortality rates of larvae feeding on foliage of distinct poplar clone ranged from only $12.04 \%$ (Control) to as high as $83.33 \%$ (TG07). The larvae exposed to foliage from clone TG04, TG07, TG16 and

Table 1. - Average larval mortality (\%) with standard errors of different insect species after feeding on field-collected foliage of control and genetically engineered hybrid poplars.

\begin{tabular}{|c|c|c|c|c|}
\hline $\begin{array}{l}\text { Transgeni } \\
\text { c clone }\end{array}$ & $\begin{array}{l}\text { M. disstria } \\
\text { (Hübner) }\end{array}$ & $\begin{array}{l}\text { L. dispar } \\
\text { (Linnaeus) }\end{array}$ & $\begin{array}{l}\text { S. candida } \\
\text { (Staudinger) }\end{array}$ & Average \\
\hline TG02 & $46.67 \pm 10.00^{b}$ & $46.67 \pm 15.28^{\mathrm{a}}$ & $26.67 \pm 10.41^{b c}$ & $40.00 \pm 2.89^{\mathrm{abc}}$ \\
\hline TG03 & $68.89 \pm 10.18^{\text {cde }}$ & $50.00 \pm 10.00^{\mathrm{ab}}$ & $25.00 \pm 5.00^{\mathrm{ab}}$ & $47.96 \pm 22.02^{b c}$ \\
\hline TG04 & $82.22 \pm 7.698^{\mathrm{ef}}$ & $60.00 \pm 10.00^{\mathrm{abc}}$ & $51.67 \pm 7.64^{\mathrm{ef}}$ & $64.63 \pm 15.80^{\mathrm{cd}}$ \\
\hline TG07 & $86.67 \pm 13.33^{\mathrm{ef}}$ & $80.00 \pm 20.00^{\mathrm{c}}$ & $83.33 \pm 2.89$ & $83.33 \pm 3.33^{\mathrm{d}}$ \\
\hline TG08 & $52.63 \pm 7.75^{\mathrm{bc}}$ & $70.00 \pm 17.32^{\mathrm{bc}}$ & $35.00 \pm 8.66^{\mathrm{bcd}}$ & $52.54 \pm 17.50^{\mathrm{bc}}$ \\
\hline TG10 & $22.22 \pm 10.18^{\mathrm{a}}$ & $40.00 \pm 10.00^{a}$ & $35.00 \pm 10.00^{\text {bcd }}$ & $32.41 \pm 9.17^{\mathrm{ab}}$ \\
\hline TG16 & $71.11 \pm 7.95^{\mathrm{de}}$ & $60.00 \pm 17.32^{\mathrm{a} b c}$ & $40.00 \pm 10.00^{\mathrm{cde}}$ & $57.04 \pm 15.77^{\mathrm{bcd}}$ \\
\hline TG20 & $86.67 \pm 13.33^{\mathrm{ef}}$ & $40.00 \pm 10.00^{\mathrm{a}}$ & $23.33 \pm 7.64^{\mathrm{ab}}$ & $50.00 \pm 32.83^{b c}$ \\
\hline TG34 & $48.89 \pm 7.76^{b}$ & $53.33 \pm 11.55^{\mathrm{ab}}$ & $41.67 \pm 10.41^{\mathrm{de}}$ & $47.96 \pm 5.89^{b c}$ \\
\hline TG53 & $95.56 \pm 7.70^{\mathrm{f}}$ & $40.00 \pm 0^{\mathrm{a}}$ & $30.00 \pm 10.00^{\text {bcd }}$ & $55.19 \pm 35.32^{\text {bcd }}$ \\
\hline TG71 & $62.50 \pm 5.35^{\text {bcd }}$ & $60.00 \pm 17.32^{\mathrm{abc}}$ & $50.00 \pm 8.66^{\mathrm{ef}}$ & $57.50 \pm 6.61^{\text {bed }}$ \\
\hline TG80 & $48.89 \pm 16.78^{b}$ & $53.33 \pm 5.77^{\mathrm{ab}}$ & $63.33 \pm 10.41^{\mathrm{f}}$ & $55.19 \pm 7.40^{\text {bcd }}$ \\
\hline Control & $11.11 \pm 3.85^{\mathrm{a}}$ & $13.33 \pm 11.55$ & $11.67 \pm 2.89^{\mathrm{a}}$ & $12.04 \pm 1.16^{\mathrm{a}}$ \\
\hline
\end{tabular}

Average represents the average larval mortality of 3 defoliators; within each column, means with the same letter are not significantly different $(\mathrm{P}=0.05)$; ANOVA FISHER's LSD test. 
TG71 exhibited larval mortality rates higher than 57\% (Table 1).

In April, the foliage of 8 transgenic clones caused a larval mortality rate of more than $50 \%$ in forest tent caterpillars after $20 \mathrm{~d}$ feeding assays. Among them, 4 transgenic clones: TG04, TG07, TG20 and TG53 were fatal to over $80 \%$ insects and TG53 was found fatal to even $95.56 \%$ insect pests (Table 1), while, the larvae given the foliage of clone TG10 disappeared only $22.22 \%$, demonstrating its weakness in defending against predators (Table 1).

In May, 3rd-instar gypsy moth was found to be more susceptible to transgenic poplars than were both forest tent caterpillar and willow moth. More than $60 \%$ larvae consuming foliage of transgenic clone TG04, TG07, TG08, TG16 and TG71 died within 5d (Table 1), which was significantly higher than that for untransformed control (only $13.33 \%)(\mathrm{P}=4.4 \mathrm{E}-4)$. The highest mortality rate (up to $80 \%$ ) was found on larvae fed with foliage from transgenic clone TG07, the lowest (40\%) for clone TG53 except the control. Interestingly, on 7th day, the whole assay was forced to end seeing as the mortality rates of all larvae given transgenic plants was over $86 \%$ without significant difference and that for control also reached $76.67 \%$.

Contrary to 3rd-instar gypsy moth, the first generation later 5th-instar willow moths appeared to be highly resistant to transgenic poplars and finished their developmental cycle without any abnormality (data not shown), and the second-generation defoliators feeding on foliage of transgenic poplars kept the insect bioassay pupating without high larval mortality rates. Nevertheless, significant differences in larval mortality rates were found in the second-generation larvae consuming foliage from distinct poplar clones $(\mathrm{P}=9.8 \mathrm{E}-9)$. The mortality rates of larvae eating foliage from clone TG04, TG07 and TG71 was all over 50\%, and even up to $83.33 \%$ larval mortality rate were observed for clone TG71 (Table 1).

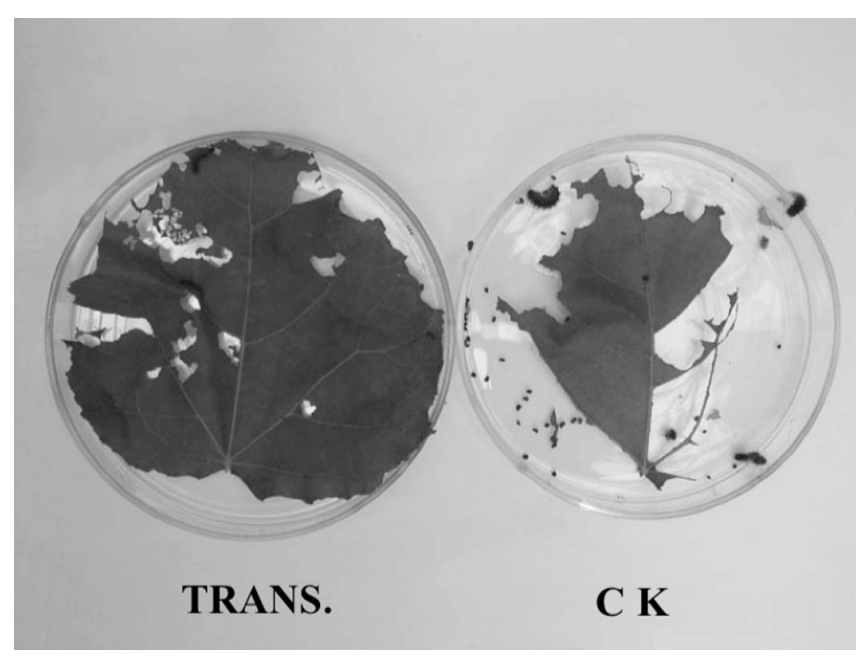

Figure 1. - Comparison of foliage consumption of 3rd-instar $S$. candida Staudinger larvae after feeding for 30h. TRANS. represents foliage of transgenic clone TG07, CK is foliage of untransformed control.
Based on the results disclosed above, 7 transgenic clones with comparatively higher efficacy against 3 species of defoliators were screened out of all transgenic poplars for the subsequent further analysis, and 3 clones TG04, TG07 and TG71were considered as the ideal transgenic poplars in afforestation for their being fatal toxicity to more than $50 \%$ larvae, particularly the best clone TG07.

\section{Foliage consumption and faeces excretion}

To investigate the effects of transgenic poplar on food intake and faeces excretion of larvae, the foliage consumption was observed first. As shown in Figure 1, 3rdinstar willow moth, like other two species of defoliators, consumed less field-collected foliage containing $C p T I$ gene, and were much smaller in body size than those larvae fed with untransformed control foliage. Later, the faeces excreted by both forest tent caterpillar and willow moth feeding on foliage of poplars for a period of $8 \mathrm{~d}$ were collected and measured. Larvae feeding on transgenic poplars excreted significant fewer faeces $(\mathrm{P}=2.3 \mathrm{E}-19$ and $\mathrm{P}=4.7 \mathrm{E}-11$, for forest tent caterpillar and willow moth, respectively) (Table 2). An average of $755 \mathrm{mg}$ of faeces were totally excreted by individual larva of forest tent caterpillar consuming foliage from control within $8 \mathrm{~d}$, and $1025 \mathrm{mg}$ by that of willow moth (Table 2), while, less than $320 \mathrm{mg}$ of faeces were collected from individual larva of forest tent caterpillar and $720 \mathrm{mg}$ from willow moth exposed to foliage from transgenic clones during the same period. Transgenic clone TG04, TG07 and TG71 elicited only $36 \mathrm{mg}, 67 \mathrm{mg}$ and $189 \mathrm{mg}$ of faeces per larva of forest tent caterpillar, respectively, and $461 \mathrm{mg}, 254 \mathrm{mg}$ and $342 \mathrm{mg}$ per larva of willow moth correspondingly (Table 2) indicating their greater effectiveness in reducing the excretion of faeces than control and other transgenic clones.

\section{Wet weight gain}

Along with the analysis of mean faeces weight, the mean wet weight gains of larvae were calculated to indirectly evaluate the effects of transgenic poplars on metabolism, growth and development of defoliators. Larvae feeding on foliage from transgenic poplars had significantly lower mean wet weight gains than did those exposed to control foliage $(\mathrm{P}=1.4 \mathrm{E}-18$ and $1.3 \mathrm{E}$ -

Table 2. - Average excreted faeces weight $(\mathrm{mg})$ with standard errors of 2 species of larvae after feeding on field collected foliage of control and transgenic hybrid poplars for a period of $8 d$.

\begin{tabular}{ccc}
\hline Transgenic clone & M. disstria (Hübner) & $\begin{array}{c}\text { S. candida } \\
\text { (Staudinger) }\end{array}$ \\
\hline TG04 & $36 \pm 7^{\mathrm{a}}$ & $461 \pm 49^{\mathrm{b}}$ \\
TG07 & $67 \pm 11^{\mathrm{a}}$ & $254 \pm 36^{\mathrm{a}}$ \\
TG08 & $191 \pm 18^{\mathrm{b}}$ & $504 \pm 42^{\mathrm{b}}$ \\
TG16 & $311 \pm 15^{\mathrm{d}}$ & $719 \pm 78^{\mathrm{d}}$ \\
TG53 & $254 \pm 38^{\mathrm{c}}$ & $519 \pm 42^{\mathrm{be}}$ \\
TG71 & $189 \pm 22^{\mathrm{b}}$ & $342 \pm 51^{\mathrm{a}}$ \\
TG80 & $289 \pm 18^{\text {cd }}$ & $628 \pm 64^{\text {cd }}$ \\
Control & $755 \pm 58$ & $1025 \pm 140$ \\
\hline
\end{tabular}

Within each column, means with the same letter are not significantly different $(\mathrm{P}=0.05)$; ANOVA FISHER's LSD test. 
Table 3. - Average wet weight gains (mg) with standard errors of 2 species of larvae after feeding on field-collected foliage of control and genetically engineered hybrid poplars.

\begin{tabular}{ccc}
\hline Transgenic clone & M. disstria (Hübner) & $\begin{array}{c}\text { S. candida } \\
\text { (Staudinger) }\end{array}$ \\
\hline TG04 & $27 \pm 6^{\mathrm{a}}$ & $163 \pm 29$ \\
TG07 & $37 \pm 4^{\mathrm{a}}$ & $23 \pm 4^{\mathrm{a}}$ \\
TG08 & $76 \pm 11^{\mathrm{c}}$ & $118 \pm 14$ \\
TG16 & $58 \pm 7^{\mathrm{b}}$ & $256 \pm 11^{\mathrm{b}}$ \\
TG53 & $62 \pm 4^{\mathrm{b}}$ & $228 \pm 9^{\mathrm{b}}$ \\
TG71 & $66 \pm 10^{\mathrm{b}}$ & $40 \pm 8^{\mathrm{a}}$ \\
TG80 & $83 \pm 6^{\mathrm{c}}$ & $359 \pm 16$ \\
Control & $141 \pm 14$ & $723 \pm 42$ \\
\hline
\end{tabular}

Within each column, means with the same letter are not significantly different $(\mathrm{P}=0.05)$; ANOVA FiSHER's LSD test.

20 , for forest tent caterpillar and willow moth, respectively) (Table 3). The mean wet weight of forest tent caterpillar consuming foliage from control was increased by $141 \mathrm{mg}$ after $20 \mathrm{~d}$ feeding, and $723 \mathrm{mg}$ for willow moth after 28d rearing. However, only less than $84 \mathrm{mg}$ and $360 \mathrm{mg}$ of mean wet weight gains were revealed in forest tent caterpillar and willow moth consuming foliage from transgenic clone, respectively. These results indicated that the transgenic foliage induced the reduction of mean wet weight gains of larvae. Further analysis found that TG04 and TG07 resulted in the increase in larval wet weight gains of forest tent caterpillar by less than $40 \mathrm{mg}$, as did TG07 and TG71for that of the willow moth, and the efficacy of these 3 clones in reducing the larval wet weight gains was further confirmed (Table 3).

\section{Pupae weight and deposited egg number}

On the 29th day of the bioassay performed on willow moth, pupae were firstly discovered in vials given control foliage. $5 \mathrm{~d}$ later they were discovered in vials containing foliage of transgenic poplars. On 38th day of the inoculation, all pupae in vials containing transgenic foliage and those given control foliage were collected and grouply weighed respectively to further investigate effects of transgenic poplars on the growth and development of larvae by calculating their mean weight. Two types of willow moth pupae given foliage from transgenic poplars had almost half weight of pupae developed from the larvae exposed to control foliage $(\mathrm{P}=1.8 \mathrm{E}-4$ and 0.02 , for female and male pupae, respectively) (Table 4), and were much smaller in physical size in comparison to control pupae (Figure 2).

After the above analysis, the pupae developed from larvae given foliage of transgenic poplars and those from control foliage were grouply incubated in 2 distinct containers in greenhouse. It is profitable for their independent hatching and copulating within distinct group. The fecundity of adult willow moths was evaluated by counting their deposited egg number. The number of deposited eggs of adult willow moth developed from larvae exposed to control foliage (132 eggs) was almost double of that for transgenic poplars (68 eggs) $(\mathrm{P}=0.03)$ (Table 4). These results demonstrated that foliage of transgenic poplars has evident effectiveness in retarding physical
Table 4. - Average pupae weight (mg) and deposited egg number with standard errors of $S$. candida Staudinger after feeding on field-collected foliage.

\begin{tabular}{ccccc}
\hline & \multicolumn{2}{c}{ Control } & \multicolumn{2}{c}{ Transgenic } \\
\cline { 2 - 5 } & Female & Male & Female & Male \\
Pupae weight $/ \mathrm{mg}$ & $378 \pm 15$ & $217 \pm 21$ & $190 \pm 13$ & $129 \pm 25$ \\
Egg number & $132 \pm 24$ & \multicolumn{2}{c}{$68 \pm 11$} \\
\hline
\end{tabular}

Control represents $S$. candida Staudinger feeding on foliage of untransformed poplars, Transgenic is $S$. candida Staudinger feeding on foliage of transgenic poplars; Female and male represent corresponding gender of S. candida Staudinger.

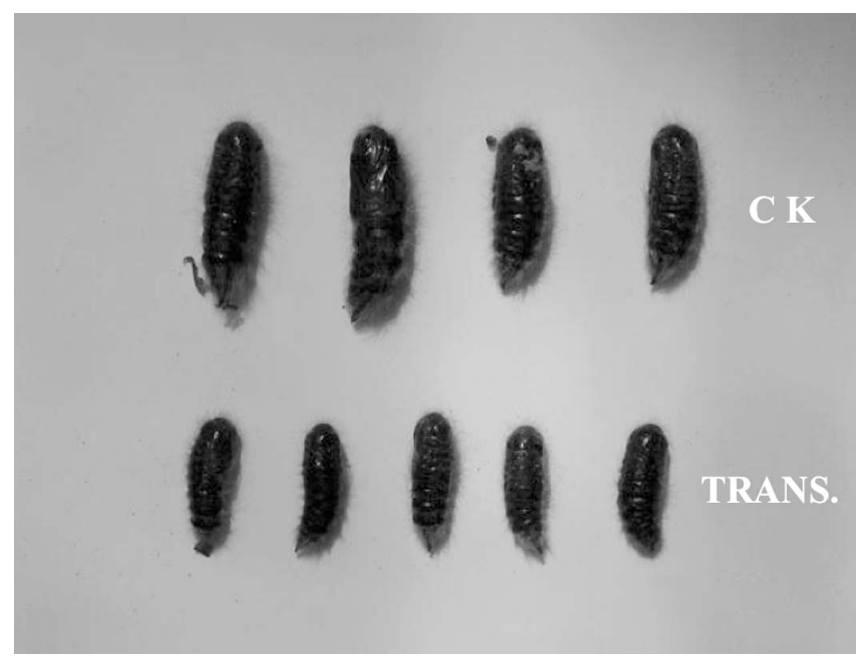

Figure 2. - Comparison of pupae size of pupated S. candida Staudinger after feeding on field-collected foliage. TRANS. represents pupae developed from larvae after feeding on foliage of transgenic poplars, CK is pupae developed from larvae after feeding on untransformed control foliage.

development of insects and affecting their fecundity as well.

\section{PCR and Southern blotting analysis}

Insect bioassay was followed by molecular identification at DNA level to determine the integration status of $C p T I$ gene in the host genome. Genomic DNA extracted from 6 transgenic poplar clones (TG04, TG07, TG08, TG16, TG53 and TG71) and one control poplar were used to perform PCR analysis with $C p T I$ gene specific primer combination. As shown in Figure 3, a clear and identical DNA fragment of about $415 \mathrm{bp}$ specific to $C p T I$ gene was observed in all transgenic lanes, while no corresponding DNA fragment was shown in non-transgenic lane. Identical results were obtained in 3 repeated experiments.

Following PCR analysis, Southern blotting experiment was performed on HindIII digested genomic DNA from 4 transgenic poplar clones (TG04, TG07, TG16 and TG71) and one control poplar. It was demonstrated that there were clear and strong hybridization signals ranging from $1.5 \mathrm{~kb}$ to $4.0 \mathrm{~kb}$ in size on lanes for all transgenic poplar clones. However, no corresponding hybridization signal in the lane for the untransformed poplar clone was observed indicating the absence of 


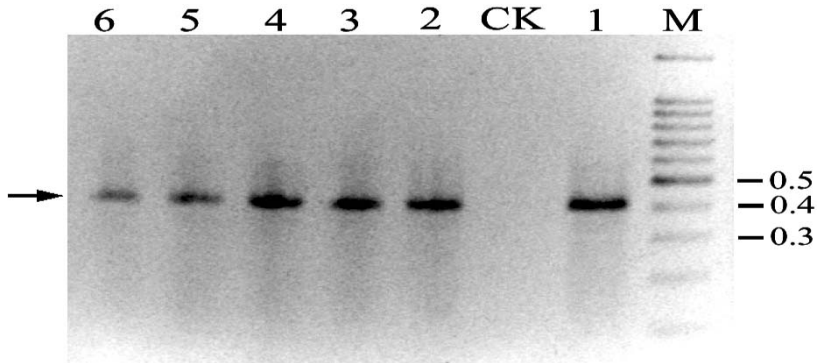

Figure 3. - PCR analysis of plant genomic DNA using CpTI gene specific primer combination. $\mathrm{M}$ is 2-kb ladder DNA Marker, CK is genomic DNA of untransformed control poplar; 1-6 represents genomic DNA of transgenic clone TG04, TG07, TG08, TG16, TG53 and TG71, respectively, arrow (left) indicates the specific bands corresponding to $C p T I$ gene, numbers (right) indicate the DNA size.

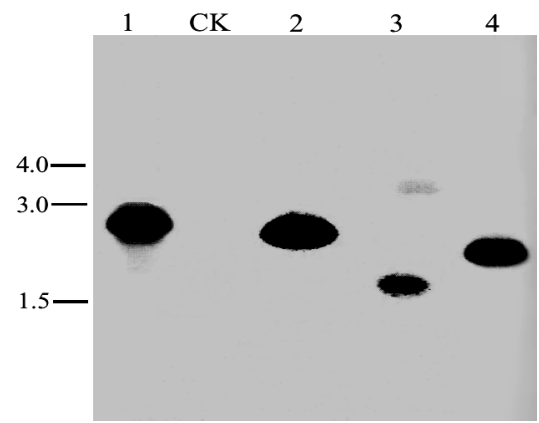

Figure 4. - Southern blot analysis of $C p T I$ gene with plant genomic DNA. $10 \mu \mathrm{g}$ of HindIII restricted genomic DNA was probed with a 100bp artificially synthesized and DIG High Prime labeled $C p T I$ gene specific DNA sequence. CK is genomic DNA of untransformed control poplar; 1-4 represents genomic DNA of transgenic clone TG04, TG07, TG16 and TG71, respectively; the numbers (left) represent 4-kb Marker.

CpTI gene in the genome of control poplar (Figure 4). The position of hybridization signals on the film differed from every other transgenic clone, which demonstrated the random incorporation loci of each copy of $C p T I$ gene in the genome of different poplar clone. Interestingly, the main hybridization signal observed on lane for TG16 was much weaker than those for other 3 transgenic clones and its position was the lowest on the film. In addition, a very dim hybridization signal was detected on the film in the lane for TG16 and its place was very close to the electrophoresis start line which could be contributed to incomplete digestion of plant genomic DNA. The above results confirmed the presence and stable incorporation of $C p T I$ gene in the host genome of twofield-season trees.

\section{Determination of CpTI content}

After insect bioassay and molecular identification at DNA level, the CpTI content in both young and old leaves of poplars with comparatively high insect resistance were determined by proteinase inhibitory assays to investigate the role of CpTI played in insect resistance and the expression feature of this gene in host genome. It was found that CpTI content in leaves from 7 tested transgenic poplar clones ranged from $9.56 \mu \mathrm{g} . \mathrm{g}^{-1}$ FW to $16.74 \mu \mathrm{g} . \mathrm{g}^{-1} \mathrm{FW}$ (Figure 5) and CpTI content in 2

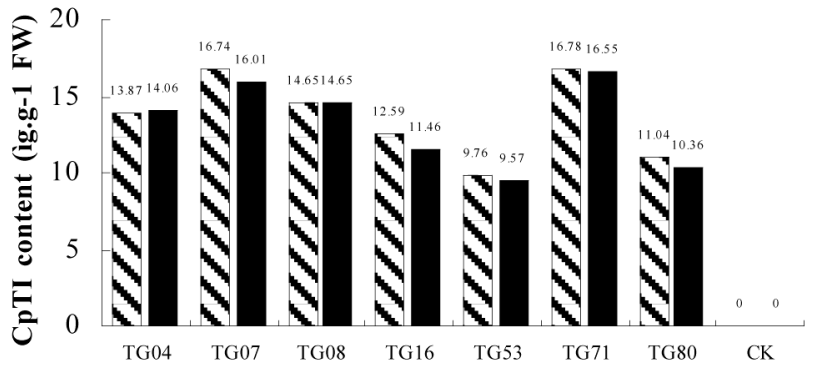

Figure 5. - CpTI content in young leaves and old leaves ( $\mu$ g. $\mathrm{g}^{-1} \mathrm{FW}$ ) detected by proteinase inhibitory assays. Hatched and black bars represent young leaves and old leaves, respectively, numbers on top of each bar indicate corresponding CpTI content.

types of leaves was very close. Most transgenic clones have more than $14.0 \mu \mathrm{g} . \mathrm{g}^{-1} \mathrm{FW}$ of $\mathrm{CpTI}$ in both young leaves and old leaves. More than $16 \mu \mathrm{g} \cdot \mathrm{g}^{-1} \mathrm{FW}$ of CpTI was detected in 2 kinds of leaves from clone TG07 and TG71. These results demonstrated that there was high amount of CpTI in both young and old leaves of each transgenic clone highly resistant to defoliators, and seemed that there was no significant difference in the expression level of $C p T I$ gene in 2 types of foliage from the same transgenic clone. However, no CpTI was detected in control plant, indicating the absence of the CpTI gene. Moreover, CpTI content detected in 2 types of leaves from clone TG04, TG07, TG08 and TG71 was much more or a little less than $14.0 \mu \mathrm{g} \cdot \mathrm{g}^{-1} \mathrm{FW}$, thus accounting for their high insect resistance.

\section{Discussion}

The role of cowpea trypsin inhibitor (CpTI) as defensive compounds against insect pests of the orders Lepidoptera, Coleoptera and Orthoptera is well established by artificial diet bioassays (BROADWAY et al., 1986; JOHNson et al., 1993; BELL et al., 2001) and insect feeding trials on genetically engineered plants (HILD et al., 1987; Boulter et al., 1989; GHoshal et al., 2001). Here, we have proved that following 2 winter dormancies transgenic poplars conferred resistance to 3 Lepidopterans by highly and constitutively expressing CpTI protein in the foliage. Although the transgenic foliage did not elicit mortality rates of willow moth after feeding trials as high as that exposed to foliage expressing Bacillus thuringiensis $\delta$-endotoxin (McCown et al., 1991; Wu et al., 1991; TIAN et al., 1993; CHEN et al., 1995), it was found to be fatal to gypsy moth and comparatively deleterious and toxic to forest tent caterpillar, and resulted in huge decrease in foliage consumption, wet weight gains, faeces excretion, deposited pupae number and pupae weight of willow moth, indicating CpTI being efficacious in retarding growth and physical development of insects and impairing their fecundity by affecting inner metabolism rather than directly killing them completely. This insect resistance phenotype was proved particularly evident on 4 transgenic clones: TG04, TG07, TG08 and TG71.

Within the mid gut of insect, CpTI binds competitively to the binding site of a target enzyme to form an 
enzyme-inhibitor (EI) complex and subsequently renders the enzyme incapable of binding to and cleaving to peptide bonds of proteins (BROADWAY et al., 1992). However, an ingestion of proteinase inhibitors does not eliminate proteolytic digestion in the midgut of insect, but leads to the accumulation of undigested food. It is followed by hyperproduction of proteolytic enzymes as a result of feedback regulation, which, in turn, induce reduced availability of essential amino acids for protein synthesis, finally resulting in retarded growth and development (LAWRENCE et al., 2002). However, processing these procedures in the gut of larvae eating foliage of transgenic poplars is completely dependent on the presence of high level CpTI protein expressed in the foliage. Being under control of constitutive CaMV 35S promoter and the modification with addition of an Omega element, a SKTI signal peptide and a KDEL coding sequence have the potential to enhance the expression level of $C p T I$ gene dramatically. This prediction was confirmed by our proteinase inhibitory assays performed on the protein extracts of leaves from 7 transgenic clones, particularly 4 clones with higher resistance against predators.

Moreover, the detection of high level CpTI in leaves and the identification of CPTI gene using PCR and Southern blotting analysis further confirmed that the stable integration and expression status of foreign $C p T I$ gene in the hosts have not been changed by the twofield-season of growing in the field.

In screening for fine transgenic clones, 3 transgenic clones: TG04, TG07 and TG71 were picked out immediately due to their outstanding performances in all indexes used for evaluating insect resistance. TG16, TG80 or TG53, rather than TG08, should be selected as the fourth prominent transgenic clone in terms of fatal toxicity to tested larvae (Table 1), while further analysis found that TG08 was superior to all of them with regard to the subsequent evaluation indexes including faeces excretion (Table 2), mean weight gains (Table 3) and CpTI content (Figure 5), which thereby determined its selection as the final fine transgenic clone.

With regard to developmental stage of tested larvae, many insect feeding bioassays performed on transgenic plants expressing $B t \delta$-endotoxin usually choose the 1 stinstar larvae as testing insects (TIAN et al., 1993; CHEN et al., 1995), and consequently revealed extremely high larval mortality rates. YANG et al. (2003) conducted feeding trials using various instar larvae, and found gradual decrease in larval mortality rates as the larvae developed. Our studies were performed on 3rd-instar larvae, and disclosed middle level larval mortality rates. It seems that developmental stage plays an important role in the response of larvae to the feeding, and that lowerinstar larvae is much more susceptible to the change of environment and food than higher-instar larvae, particularly 1st-instar larvae due to their weakness. Therefore, the best way to acquire convincing results of insect feeding assays would be to perform such test using larvae at different developmental stage.

Besides the lab tests under controlled condition, revealing the performances of transgenic poplars in the field is much more important because of their final usage in afforestation, and has been under way. Their fine performances in lab tests ever led to an expectation that the growth status of transgenic poplars should be better than untransformed poplars as a result of reduction in damage to leaves, twigs, roots or stems caused by insect pests. However, according to our current field investigation, no significant difference in growth status and damage degree between transgenic and untransformed poplars has been discovered (data not shown). One possible reason is that both transgenic and untransformed poplars in our small area of test field separated from other forest stands are not ideal hosts to local insect pests, or cannot provide a fitting environment for their survival. Moreover, this result from field investigation also identified that the growth status of transgenic poplars has not been interfered by the incorporation of foreign $C p T I$ gene. Nevertheless, what their success rate in insect resistance and growth status would be once they were actually used in afforestation remains uncertain, and requires further investigation, because the change in environment, the management and the interference of surrounding creatures (particularly human beings etc) have the potential to make what has been observed in lab tests under controlled conditions inapplicable to actual field condition.

\section{Acknowledgements}

This project was funded by the National Project in Transgenic Plant and Application (Grant No. J2002-B003). We thank Prof. Z. Y. LI and Associate Prof. X. SHEN from Beijing Forestry University for their support in insect feeding bioassays and molecular detection and Prof. Dr. G. MülLER-STARCK from Ludwig-MaximiliansUniversität München for his help in paper revision.

\section{References}

Bell, H. A., E. C. Fitches, R. E. Down, L. Ford, G. C. Marris, J. P. Edwards, J. A. Gatehouse and A. M. GateHOUSE (2001): Effect of dietary cowpea trypsin inhibitor (CpTI) on the growth and development of the tomato moth Lacanobia oleracea (Lepidoptera: Noctuidae) and on the success of the gregarious ectoparasitoid Eulophus pennicornis (Hymenoptera: Eulophidae). Pest Manag. Sci. 57: 57-65.

Boulter, D., A. M. Gatehouse and V. Hilder (1989): Use of cowpea trypsin inhibitor (CpTI) to protect plants against insect predation. Biotech. Adv. 7: 489-97.

BroAdwAY, R. M. and A. A. Colvin (1992): Influence of cabbage proteinase inhibitors in situ on the growth of larval Trichoplusia ni and Pieris rapae. J. Chem. Ecol. 18: 1009-1023.

BroADWAY, R. M. and S. S. DUfFEy (1986): The effect of dietary protein on the growth and digestive physiology of larval Heliothis zea and Spodoptera exigua. J. Insect Physiol. 32: 673-680.

Campbell, M. M., A. M. Brunner, H. M. Jones and S. H. STRAUSS (2003): Forestry's fertile crescent: the application of biotechnology to forest trees. Plant Biotech. J. 1: 141-154.

Chen, Y., Y. F. HAN, Y. C. TIAN, L. Li and S. J. NiE (1995): Study on the plant regeneration from Populus deltoids explants transformed with B. t. toxin gene. Scientia Silvae Sinica. 31: 97-103. 
Confalonieri, M., G. Allegro, A. Balestrazzi, C. Fogher and M. Delledonne (1998): Regeneration of Populus nigra transgenic plants expressing a Kunitz proteinase inhibitor (KTi) gene. Molecular Breeding. 4: 137-145.

Delle Donne, M., G. Allegro, B. Belenghi, A. Balestrazzi, F. Picco, A. Levine, S. Zelasco, P. CalliGARI and M. CONFALONIERI (2001): Transformation of white poplar (Populus alba L.) with a novel Arabidopsis thaliana cysteine proteinase inhibitor gene and analysis of insect pest resistance. Molecular Breeding. 7: $35-42$.

Ghoshal, D., S. K. Sen and A. Goyal (2001): Introduction and expression of cowpea trypsin inhibitor (CpTI) gene in transgenic tobacco. J. Plant Biochem. Biotech. 10: 19-24.

Hammond, R. W., D. E. Foard and B. A. LaRkins (1984): Molecular cloning and analysis of a gene coding for the Bowman-Birk protease inhibitor in soybean. J. Biol. Chem. 259: 9883-9890.

HAO, G. X., Z. ZHU and Z. T. ZHU (1999a): Study on optimization transformation of Populus tomentosa. Acta Botanica Sinica. 41: 936-941.

HAO, G. X., Z. ZHU and Z. T. ZHU (1999b): Transformation of Populus tomentosa with insecticidal cowpea proteinase inhibitor gene. Acta Botanica Sinica. 41: 1276-1282.

Heuchelin, S. A., H. S. McNabB and N. B. KLOpFenstein (1997): Agrobacterium-mediated transformation of Populus $\mathrm{x}$ euramericana 'Ogy' using the chimeric CaMV 35S-pin2 gene fusion. Can. J. For. Res. 27: 1041-1048.

Hilder, V. A., R. F. Barker, R. A. Samour, A. M. R. GateHouse, J. A. GATEhouse and D. Boulter (1989): Protein and cDNA sequences of Bowman-Birk protease inhibitors from the cowpea (Vigna unguiculata Walp.). Plant Mol. Biol. 13: 701-710.

Hilder, V. A., A. M. R. Gatehouse and D. Boulter (1990): In: Genetic engineering of crop plants (LYCETT, G., GRIERSON, D., Editors) Boston: Butterworths, London, pp 51-66.

Hilder, V. A., A. M. R. Gatehouse, S. E. Sheerman, R. F. BARKER and D. A. Boulter (1987): A novel mechanism of insect resistance engineered into tobacco. Nature. 330: $160-163$.

Johnston, K. A., J. A. Gatehouse and J. H. Anstee (1993): Effects of soybean proteinase inhibitor on the growth and development of larval Helicoverpa armigera. J. Insect Physiol. 39: 657-664.

KLOPFEnstein, N. B., N. Q. SHi, A. Kernan, H. S. MCNABb, R. B. HALl, E. R. HART and R. W. ThORNBURG (1991): Transgenic Populus hybrid expresses a wound-inducible potato proteinase inhibitor II-CAT gene fusion. Can. J. For. Res. 21: 1321-1328.

Lawrence, P. K. and K. R. Koundal (2002): Plant protease inhibitors in control of phytophagous insects. Electronic J. Biotech. 5: 1-17.

Leple, J. C., M. Bonade-Bottino, S. Augustin, G. Pilate, L. E. Dumanois, V. Tan, A. Delplanque, D. Cornu and L. JouAnin (1995): Toxicity to Chrysomela tremulae (Coleoptera: Chrysomelidae) of transgenic poplars expressing a cysteine proteinase inhibitor. Molecular Breeding. 1: 319-328.

LI, J. Y. and Z. Y. ZHANG (2000a): Genetic variation in photosynthetic traits of triploid clones of Populus tomentosa. J. Beijing For. Uni. 22: 12-15.

Li, M. L., H. Zhang, J. J. Hu, Y. F. HAN and Y. C. Tian (2000b): Study on insect-resistant transgenic poplar plants containing both $B t$ and $P I$ gene. Scientia Silvae Sinicae. 36: 93-97.
LiU, C. M., Z. ZHu, Z. L. Zhou, B. L. Sun and X. H. LI (1993): cDNA clone and expression of cowpea trypsin inhibitor in Escherichia coli. Chin. J. Biotech. 9: 152-157.

Lu, S. F., H. Y. ZhaO, J. H. Wei and Y. R. Song (2001): Establishment of in vitro regeneration system of triploid Chinese white poplar. Acta Botanica Sinica. 43: 435-437.

McCown, B. H., D. E. McCabe, D. R. Russell, D. J. RobISON, K. A. BARTON and K. F. RAFFA (1991): Stable transformation of Populus and incorporation of pest resistance by electric discharge particle acceleration. Plant Cell Reports. 9: 590-594.

Pannetier, C., M. Giband, P. Couzi, V. Letan, M. Mazier, J. TourneuR and B. HAU (1997): Introduction of new traits into cotton through genetic engineering: insect resistance as example. Euphytica. 96: 163-166.

PERLAK, F. J., R. L. FuChS, D. A. DEAN, S. L. McPherson and D. A. Fischioff (1991): Modification of the coding sequence enhances plant expression of insect control protein gene. Pro. Natl. Acad. Sci. USA. 88: 3324-3328.

PU, J. W., J. L. Song, Y. M. XIE and R. J. GU (2002): Characteristics of lignin structure of triploid clones of Populus tomentosa Carr. J. Beijing For. Uni. 24: 211-215.

Rogers, S. O. and A. J. BENDICH (1985): Extraction of DNA from milligram amounts of fresh, herbarium, and mummified plant tissues. Plant Mol. Biol. 5: 1041-1045.

Rosner, B. (2004): Fundamentals of Biostatistics. Ed 5. Thomson Learning and Science Press. USA.

RYAN, C. A. (1989): Proteinase inhibitor gene families: Strategies for transformation to improve plant defense against herbivores. Biol. Essays. 10: 20-24.

RYAN, C. A. (1990): Protease inhibitors in plants: genes for improving defenses against insects and pathogens. Ann. Rev. Phytopath. 28: 425-449.

SAMBRoOK, J., E. F. Fritsch and T. MANiATis (1989): Molecular Cloning: A Laboratory Mannual, Ed 2. Cold Spring Harbor Laboratory Press, Cold Spring Harbor, NY.

TIAN, Y. C., T. Y. LI, K. Q. MANG, L. LI and Y. F. HAN (1993): Insect tolerance of transgenic Populus nigra plants transformed with a Bacillus thuringiensis toxin gene. Chin. J. Biotech. 9: 291-297.

Tian, Y. C., J. B. Zheng, H. M. Yu, H. Y. Liang, C. C. Li and M. S. WANG (2000): Studies of transgenic hybrid poplar 741 carrying two insect-resistant genes. Scientia Silvae Sinicae. 42: 263-268.

Urwin, P. E., H. J. Atkinson, D. A. Waller and M. J. MCPHERSON (1995): Engineered oryzacystatin I expressed in hairy roots confers resistance to Globodera pallida. Plant J. 8: 121-131.

Whitman, T. G., K. D. Floate, G. D. Martinsen, E. M. DRIEBE and P. KEIM (1996): Ecological and evolutionary implications of hybridizations: Populus-herbivore interactions. In: Stettler, R. F., Bradshaw, JR. H. D., HeilMAN, P. E., Hinckley, T. M., editors; StetTleR, R. F., Bradshaw, JR. H. D., Heilman, P. E., Hinckley, T. M., editors. Biology of Populus and its implications for management and conservation. Ottawa, Canada: NRC Research Press, pp 247-275.

WU, N. F. and Y. L. FAN (1991): Establishment of engineered poplars containing Bacillus thuringiensis $\delta$-endotoxin gene. Chin. Sci. Bull. 9: 705-708.

XING, X. T. and Z. Y. ZHANG (2002): Genetic control of airdried wood density, mechanical properties and its appli- 
cation for veneer timber breeding of new triploid clones in Populus tomentosa Carr.. Forestry Studies in China, 4: $52-60$.

Xu, W. Y. (1988): Poplar, Helongjiang People Press, Harbin, Heilongjian Province, China, pp 297.

Xu, D. P., Q. Z. Xue, D. McElroy, Y. MaWal, V. A. Hilder and R. WU (1996): Constitutive expression of a cowpea trypsin inhibitor gene, $C p T I$, in transgenic rice plants confers resistance to two major rice insect pests. Molecular Breeding. 2: 167-173.

YANG, M. S., H. Y. LANG, G. J. GAO, J. M. WANG and J. B. ZHENG (2003): Insecticidal activity and transgene expression stability of transgenic hybrid poplar clone 741 carrying two insect-resistant genes. Silvae Genetica. 52: 5-6.
Zhang, Z. Y., F. L. Li and Z. T. ZHU (1992): Chromosome doubling and triploid breeding of Populus tomentosa Carr. and its hybrid. J. Beijing For. Uni. 14(supp): $52-58$.

ZHANG, Z. Y., F. L. Li and Z. T. ZHU (1997b): Doubling technology of pollen chromosome of Populus tomentosa and its hybrids, J. Beijing For. Uni. (English Ed.) 6: 9-20.

Zhang, Z. Y., X. S. YU and Z. T. ZHU (2000): Sexual reproduction of hybrid triploids in Populus tomentosa. J. Beijing For. Uni. 22: 1-4.

Zhang, Z. Z. (1997a): Forest Entomology. China Forestry Publishing House. Beijing, pp 221.

ZHU, Z. T. and Z. Y. ZHANG (1997): Status and advances of genetic improvement of Populus tomentosa Carr.. J. Beijing For. Uni. (English Ed.) 6: 1-7.

\title{
Population Genetic Survey of Populus cathayana Originating From Southeastern Qinghai-Tibetan Plateau of China Based on SSR Markers
}

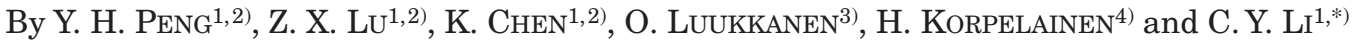

(Received 1 ${ }^{\text {st }}$ April 2005)

\begin{abstract}
In this study, the genetic diversity of Populus cathayana Rehd was investigated using microsatellite markers. In a total of 150 individuals collected from six natural populations in the southeastern part of the Qinghai-Tibetan Plateau in China, a high level of microsatellite polymorphism was detected. At the seven investigated microsatellite loci, the number of alleles per locus ranged from 5 to 16 , with a mean of 11.3 , the observed heterozygosities across populations ranged from 0.408 to 0.986 , with a mean of 0.792 , and the expected heterozygosities across populations ranged from 0.511 to 0.891 , with a mean of 0.802 . The proportion of genetic differentiation among populations accounted for $37.3 \%$ of the whole genetic diversity. The presence of such a high level of genetic diversity could be attributed to the features of the species and the habitats where the sampled populations occur: The southeastern part of the Qinghai-Tibetan Plateau is regarded as the natural distribution and variation center of the genus Populus in China. Variation in environmental

1) Chengdu Institute of Biology, Chinese Academy of Sciences, P.O. Box 416, Chengdu 610041, P. R. China.

2) Graduate School of the Chinese Academy of Sciences, Beijing 100039, P. R. China.

3) Viikki Tropical Resources Institute, P.O.Box 28, FI-00014 University of Helsinki, Finland.

4) Department of Applied Biology, P.O. Box 27, FI-00014 University of Helsinki, Finland.

*) Correspondence address: ChunYang Li, Chengdu Institute of Biology, Chinese Academy of Sciences, P.O. Box 416, Chengdu 610041, P. R. China, Tel: +86-28-85221347, Fax: +8628-85222753, Email: licy@cib.ac.cn, chunyang.li@helsinki.fi
\end{abstract}

conditions and selection pressures in different populations, and topographic dispersal barriers could be factors associated with the high level of genetic differentiation found among populations. The populations possessed significant heterozygosity excesses, which may be due to extensive population mixing at the local scale. The cluster analysis showed that the populations are not strictly grouped according to their geographic distances but the habitat characteristics also influence the divergence pattern. In addition, we suggest that population SHY should be regarded as an ecologically divergent species of $P$. cathayana.

Key words: Genetic differentiation, Genetic diversity, Heterozygosity excess, Microsatellites, Populus cathayana.

\section{Introduction}

The Qinghai-Tibetan Plateau is the largest and highest plateau of the world, located in southwestern China. Due to its unique geographical and geological historical factors, variable terrain and complex climatic conditions, the Qinghai-Tibetan Plateau, especially its southern and eastern mountain areas, has abundant and special resources of the genus Populus, and it is regarded as the natural distribution and variation center of genus Populus in China (Weisgerber and Han, 2001; YU, 2003). Many Populus species, mainly of Sect. Tacamahaca Spach, occur in the mountains and canyon belts between the plateau and plain at altitudes varying between 1,500-4,300 $\mathrm{m}$ above sea level. Most native species of this section have strong resistance against stressful environments, and they are used as important genetic resources for plantation and breeding work in 